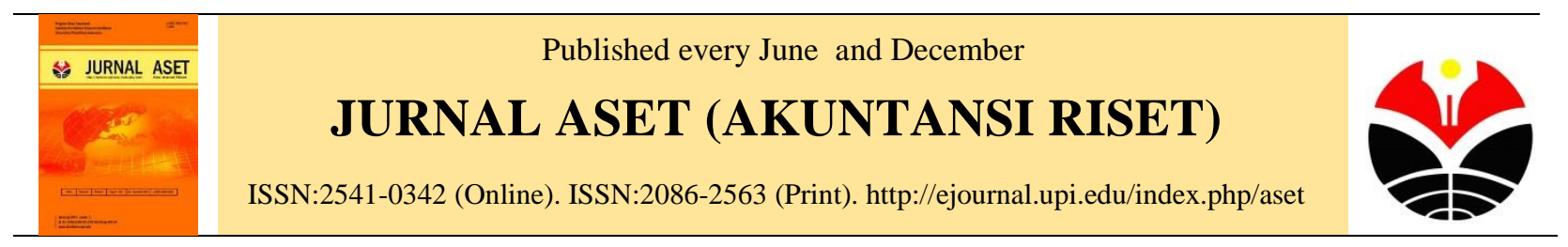

\title{
Locus Of Control, Tekanan Ketaatan dan Kompleksitas Tugas Terhadap Audit Judgment
}

\author{
Dessy Indah Sari ${ }^{1}$, Endang Ruhiyat ${ }^{2}$ \\ Prodi Akuntansi, Fakultas Ekonomi, Universitas Pamulang, Tangerang Selatan \\ dessyindah31@gmail.com ${ }^{1}$, holenroe@yahoo.co.id ${ }^{2}$
}

\begin{abstract}
This research was aimed to obtain empirical evidents on effects of locus of control, obedience pressure, and taks complexity on audit judgment. The population of this research is auditors who worked on Public Accountant Offices in Tangerang which listed on Directory IAPI on October 2016. The sampling was conducted by purposive sampling technique and the sample used in this research was 52 respondent. Collecting data was conducted by questionnaire instrument. The method of analysis was used to test the hypothesis is multiple linear regression. The result of research showed that locus of control has a significant positive effect on audit judgment; obedience pressure has a significant negative effect on audit judgment; and task complexity has a significant negative effect on audit judgment.
\end{abstract}

Keywords: Audit Judgment; Locus of Control; Obedience Pressure; Task Complexity

Abstrak. Penelitian ini bertujuan untuk memperoleh bukti secara empiris pengaruh locus of control, tekanan ketaatan, dan kompleksitas tugas terhadap audit judgment. Populasi penelitian ini adalah auditor yang bekerja pada Kantor Akuntan Publik diwilayah Tangerang yang terdaftar di directory IAPI per Oktober 2016. Pengambilan sampel menggunakan teknik purposive sampling, dan sampel yang digunakan berjumlah 52 responden. Pengumpulan data dilakukan dengan menggunakan instrumen kuesioner. Metode analisis yang digunakan untuk menguji hipotesis adalah regresi linier berganda. Hasil penelitian ini menunjukan bahwa locus of control berpengaruh signifikan positif terhadap audit judgment; tekanan ketaatan berpengaruh signifikan negatif terhadap audit judgment; dan kompleksitas tugas berpengaruh signifikan negatif terhadap audit judgment

Kata kunci: Audit Judgment; Locus of Control; Obedience Pressure; Task Complexity

Corresponding author. dessyindah31@ gmail.com, holenroe@ yahoo.co.id

How to cite this article. Indah, Ruhiyat. Locus Of Control, Tekanan Ketaatan dan Kompleksitas Tugas Terhadap Audit Judgment. Jurnal Akuntansi Riset. Program Studi Akuntansi. Fakultas Pendidikan Ekonomi dan Bisnis Universitas Pendidikan Indonesia, 9 (2), 23-34

History of article. Received: September 2017, Revision: November 2017, Published: Desember 2017 


\section{PENDAHULUAN}

Laporan keuangan merupakan proses akhir dari akuntansi yang akan digunakan dalam pengambilan keputusan banyak pihak. Sebuah laporan keuangan yang baik adalah laporan yang mampu memberikan pemahaman dan informasi yang memadai dan mudah dipahami oleh para pemangku kepentingan agar mereka mampu dengan akurat mengambil keputusan terhadap keberlangsungan suatu entitas. Oleh karena itu untuk mengetahui kewajaran dan keakuratan suatu laporan keuangan serta menjamin kualitas informasi yang ditampilkan di dalamnya dibutuhkan jasa pihak ketiga yaitu auditor. Hal ini juga didukung oleh peraturan BAPEPAM Nomor Kep-36/PM/2003 dan Peraturan Bursa Efek Jakarta (BEJ) Nomor Kep-306/BEJ/07-2004 yang menyatakan bahwa perusahaan yang go public diwajibkan menyampaikan laporan keuangan yang disusun sesuai dengan Standar Akuntansi keuangan dan telah diaudit oleh akuntan publik atau auditor.

Akan tetapi banyak kasus skandal keuangan yang terjadi pada perusahaan besar seperti Enron (2001), Xerox (2001), Adelphia (2002), AOL (2002), Bristol-Myers Squibb (2001), Freddie Mac (2007), Kmart (2002), Tyco International (2002), Sunbeam (1998), dan WorldCom (2001), dan kasus yang terjadi di Indonesia seperti kasus laporan keuangan ganda Bank Lippo (2002), kasus manipulasi laporan keuangan PT. Kereta Api Indonesia (2006), kasus mark-up harga pada PT.Kimia Farma (2001), kasus PT.Telkom yang terjepit di antara Akuntan serta kasus-kasus lainnya (2002) (Bachtiar, 2012:5). Skandal-skandal tersebut walaupun sudah terjadi bertahuntahun lalu namun dianggap masih dianggap relevan untuk didiskusikan di kalangan akuntan dan auditor, agar hal yang sama tidak terulang lagi di kemudian hari. Skandal Toshiba Corporation (2015) dan Garuda Indonesia (2015) menambah panjang kasuskasus yang melibatkan profesi akuntan publik atau auditor di dalamnya baik secara langsung maupun tidak langsung seperti ketidakmampuan mendeteksi risiko audit. Hal ini menyebabkan kepercayaan publik menurun terhadap hasil kerja dari profesi akuntan publik tersebut. Publik menilai auditor tidak bisa melakukan tugasnya dengan baik untuk memastikan dan menjamin bahwa penyajian laporan keuangan dari suatu entitas yang diauditnya wajar dan telah sesuai dengan peraturan dan ketentuan yang berlaku tanpa ada informasi yang nantinya akan menyesatkan pengguna dari laporan keuangan tersebut.

Dalam melaksanakan audit dan memberi opini kewajaran suatu laporan keuangan, dibutuhkan suatu judgment didalam proses audit tersebut (Zulaikha, 2006). Hogart (1992) mengartikan audit judgment sebagai proses kognitif yang merupakan perilaku pemilihan keputusan. Jamilah, dkk. (2007) menjelaskan audit judgment sebagai kebijakan auditor dalam menentukan pendapat mengenai hasil auditnya yang mengacu pada pembentukan suatu gagasan, pendapat atau perkiraan tentang suatu objek, peristiwa, status, dan jenis peristiwa lainnya. Audit judgment akan mempengaruhi kualitas dari hasil audit, sehingga kualitas dari judgment ini akan menunjukan seberapa baik kinerja seorang auditor dalam melakukan tugasnya (Nadhiroh, 2010).

Di dalam melakukan audit judgment, auditor dipengaruhi oleh banyak faktor, baik faktor yang bersifat teknis maupun non-teknis (Praditaningrum, 2012). Seperti yang diungkapkan oleh Mayer (2001) dalam Jamilah, dkk (2007) beberapa faktor teknisnya seperti, keterbatasan waktu, pembatasan lingkup audit, pengetahuan, pengalaman, tekanan dari atasan ataupun entitas yang diaudit, serta kompleksitas tugas di dalam menjalankan penugasan audit. Sedangkan untuk faktor non-teknis salah satunya adalah locus of control. Berdasarkan latar belakang di atas, maka rumusan masalahnya adalah sebagai berikut : (1) Apakah locus of control berpengaruh terhadap audit judgment?; (2) apakah tekanan ketaatan berepngaruh terhadap audit judgment?; dan (3)apakah kompleksitas tugas berpengaruh terhadap audit judgment? 


\section{KAJIAN LITERATUR Teori Atribusi}

Konsep yang mendasari teori tentang audit judgment merujuk pada teori akuntansi keperilakuan khususnya teori atribusi. Teori atribusi mempelajari bagaimana seseorang menginterpretasikan alasan atau sebab perilakunya. Robbins (2003:177) mengemukakan teori atribusi sebagai perilaku seseorang yang disebabkan oleh faktor internal atau faktor eksternal. Sehingga di dalam penelitian ini teori atribusi dapat dihubungkan dengan proses pembuatan audit judgment, di mana auditor dalam membuat suatu judgment dipengaruhi faktor dari dalam diri auditor seperti locus of control dan faktor dari luar seperti tekanan ketaatan dan kompleksitas tugas.

\section{Teori X dan Y}

Teori yang dapat dijadikan landasan konsep locus of control adalah teori X dan Y yang dikembangkan oleh McGregor (1960). McGregor (1960) mengemukakan dua pandangan mengenai manusia yaitu teori $\mathrm{X}$ (negatif) dan teori $\mathrm{Y}$ (positif). Individu yang bertipe $\mathrm{X}$ memiliki locus of control eksternal di mana mereka pada dasarnya tidak menyukai pekerjaan, berusaha menghindarinya dan menghindari tanggung jawab, sehingga mereka harus dipaksa atau diancam dengan hukuman untuk mencapai tujuan. Bertentangan dengan individu bertipe $X$, McGregor (1960) menyebutkan individu yang bertipe Y memiliki locus of control internal di mana mereka menyukai pekerjaannya, mampu mengendalikan diri untuk mencapai tujuan, bertanggung jawab, dan mampu membuat keputusan inovatif.

Auditor dengan tipe $\mathrm{X}$ tidak dapat melaksanakan tanggung jawabnya sebagai auditor yang mengakibatkan tujuan audit tidak dapat tercapai dengan baik. Auditor tipe X ini juga lebih suka menaruh keamanan di atas semua faktor yang dikaitkan dengan kerja,sehingga ketika mendapat tekanan ketaatan maupun menghadapi tugas yang kompleks maka ia akan cenderung mencari jalan yang aman dan bahkan berperilaku disfungsional dalam membuat judgment.
Sedangkan auditor yang termasuk dalam tipe $Y$ dapat bertanggung jawab atas tugasnya dan tetap bersikap profesional dalam menjalankan tugas sebagai auditor. Auditor dengan tipe ini tidak akan terpengaruh meskipun ia mendapat tekanan ketaatan dan menghadapi tugas yang kompleks, sehingga dapat membuat judgment lebih baik dan tepat.

\section{Teori Penetapan Tujuan}

Teori ini menguraikan hubungan antara tujuan yang ditetapkan dengan prestasi kerja. Teori ini juga menjelaskan bahwa karyawan yang memahami tujuan yang diharapkan organisasi terhadapnya maka akan berpengaruh terhadap perilaku kerjanya. Tujuan akan memberi tahu seorang individu apa yang harus dilakukan dan berapa banyak usaha yang harus dikeluarkan. Teori ini menunjukan bahwa auditor harus mampu memahami tujuan dan apa yang dia harapkan atas hasil kinerjanya, ketika auditor mampu memahami tujuannya, auditor diharapkan tidak akan bersikap menyimpang ketika mendapatkan tekanan dari atasan atau entitas yang diperiksa dan tugas audit yang kompleks. Pemahaman mengenai tujuannya dapat membantu auditor membuat suatu audit judgment yang baik. Auditor seharusnya memahami bahwa tugas auditor adalah memberikan jasa profesional untuk menilai kewajaran informasi keuangan yang disajikan manajemen kepada pihak yang berkepentingan terhadap laporan keuangan tersebut (Margaret, 2014). Melalui pemahaman ini auditor akan tetap bersikap profesional sesuai dengan etika profesi dan standar profesional yang berlaku meskipun menghadapi tekanan dari berbagai pihak dan tugas audit yang kompleks.

\section{Audit Judgment}

Audit judgment merupakan suatu pertimbangan pribadi atau cara pandang auditor dalam menanggapi informasi yang mempengaruhi dokumentasi bukti audit serta pembuatan keputusan pendapat auditor atas laporan keuangan suatu entitas. Judgment dibutuhkan auditor dalam melaksanakan audit atas laporan keuangan suatu entitas (Zulaikha, 2006). Audit judgment melekat pada setiap 
tahap dalam proses audit, yaitu penerimaan perikatan audit, perencanaan audit, pelaksanaan pengujian audit, dan pelaporan audit. Hogart (1992) mengartikan audit judgment sebagai proses kognitif yang merupakan perilaku pemilihan keputusan. Puspa (2013:20) mendefinisikan audit judgment sebagai cara pandang auditor dalam menanggapi informasi berhubungan dengan tanggung jawab dan risiko audit yang akan dihadapi oleh auditor sehubungan dengan judgment yang dibuatnya.

\section{Locus of Control}

Locus of control merupakan salah satu variabel kepribadian (personility), yang didefinisikan sebagai keyakinan individu terhadap mampu tidaknya mengontrol nasib (destiny) sendiri (Kreitner dan Kinicki, 2005). Locus of control individual mencerminkan tingkat keyakinan seseorang tentang sejauh mana perilaku atau tindakan yang mereka perbuat mempengaruhi keberhasilan atau kegagalan yang mereka alami. Robbins dan Judge (2007) mendefinisikan lokus kendali sebagai tingkat di mana individu yakin bahwa mereka adalah penentu nasib mereka sendiri. Menurut Rotter (1990) dalam Engko dan Gudono (2007) locus of control merupakan persepsi individu pada suatu kejadian, dapat atau tidaknya individu tersebut mengendalikan suatu kejadian yang terjadi. Locus of control adalah cara pandang individu tentang hal-hal yang menyebabkan berhasil atau tidaknya individu tersebut dalam melakukan kegiatan (Hejele dan Zeigler dalam Raiyani dan Suputra, 2014).

\section{Tekanan Ketaatan}

Dalam penelitian ini tekanan ketaatan diartikan sebagai tekanan yang diterima oleh auditor dalam menjalankan pekerjaan auditnya baik dari entitas atau klien yang diperiksa untuk melakukan tindakan yang menyimpang dari standar etika demi tujuan dari entitas atau klien yang diperiksa. Mangkunegara (2005) dalam Margaret (2014) mengemukakan tekanan ketaatan sebagai suatu kondisi ketegangan yang menciptakan adanya ketidakseimbangan fisik dan psikis, yang mempengaruhi emosi, proses berpikir, dan kondisi seorang karyawan, dalam hal ini tekanan yang ada disebabkan oleh lingkungan pekerjaan di mana karyawan tersebut berkerja. Yustrianthe (2012) menyatakan bahwa auditor akan merasa dalam tekanan ketaatan saat mendapatkan perintah dari atasan atau dari klien untuk melakukan yang mereka inginkan yang mungkin bertentangan dengan standar dan etika profesi auditor. Tekanan dari atasan maupun entitas yang diperiksa juga dapat memberikan pengaruh yang buruk seperti hilangnya profesionalisme dan hilangnya kepercayaan publik dan kredibilitas sosial. Tekanan ketaatan dapat semakin kompleks ketika auditor dihadapkan pada situasi konflik. Tekanan ketaatan dapat menghasilkan variasi pada judgment auditor dan memperbesar kemungkinan pelanggaran standar etika dan profesional (Jamilah, dkk, 2007).

\section{Kompleksitas Tugas}

Kompleksitas tugas merupakan suatu tugas yang kompleks dan rumit. Sehingga membuat para pengambil keputusan harus meningkatkan kemampuan daya pikir dan kesabaran dalam menghadapi masalahmasalah di dalam tugas tersebut. Di sini pengambil keputusan atau auditor pada khususnya dituntut untuk mengembangkan pola pikir, kreativitas dan inovasinya agar tugas yang kompleks tersebut dapat terselesaikan dengan lancar. Tugas audit cenderung merupakan tugas yang kompleks, berbeda-beda dan saling terkait satu dengan lainnya. Kompleksitas audit didasarkan pada persepsi individu tentang kesulitan suatu tugas audit. Persepsi ini menimbulkan kemungkinan bahwa suatu tugas audit sulit bagi seseorang, namun mungkin juga mudah bagi orang lain (Restuningdiah dan Indriantoro, 2000).

Kompleksitas dapat muncul dari ambiguitas dan struktur yang lemah, baik dalam tugastugas utama maupun tugas-tugas yang lain (Restuningdiah dan Indriantoro, 2000). Engko dan Gudono (2007) mengemukakan kompleksitas tugas sebagai fungsi dari tugas itu sendiri, merupakan tugas yang tidak terstruktur, membingungkan, dan sulit. Menurut Kahneman, et al (2011 : 247) 
kompleksitas tugas dianggap identik dengan tugas yang sangat sulit (diperlukan kapasitas perhatian atau proses mental yang baik) atau struktur tugas yang rumit (tingkat spesifikasi apa yang harus dilakukan dalam tugas). Kompleksitas tugas juga dapat diartikan sebagai tingkat kesulitan dan variasi pekerjaan terutama dalam bentuk tekanan terhadap mental dan psikis orang yang melakukan pekerjaan (Ruky, 2011).

\section{Pengembangan Hipotesis}

Locus of control adalah cara pandang individu tentang hal-hal yang menyebabkan berhasil atau tidaknya individu tersebut dalam melakukan kegiatan (Hejele dan Zeigler dalam Raiyani dan Suputra, 2014). Raiyani dan Suputra (2014), Mahaputra (2016), Dewi (2016), dan Retnowati (2009) dalam penelitiannya menyimpulkan bahwa locus of control berpengaruh positif terhadap audit judgment. Artinya semakin tinggi tingkat locus of control yang dimiliki oleh seorang auditor, maka audit judgment yang dihasilkan oleh auditor tersebut akan semakin baik. Seorang auditor yang memiliki locus of control yang lebih baik dapat mengatasi stres dan lingkungan kerja yang lebih tinggi sehingga akan menghasilkan judgment yang lebih baik dan tepat, sedangkan auditor yang memiliki locus of control yang rendah akan cenderung menghasilkan judgment yang kurang tepat. Semakin tinggi locus of control yang dimiliki oleh seorang auditor, maka judgment yang dihasilkannya pun akan semakin baik dan tepat. Berdasarkan uraian di atas dan hasil penelitian sebelumnya, maka dapat dirumuskan hipotesis sebagai berikut:

\section{H1 : Locus of Control Berpengaruh Terhadap Audit Judgment}

\footnotetext{
Mangkunegara (2005) dalam Margaret (2014) mengemukakan tekanan ketaatan sebagai suatu kondisi ketegangan yang menciptakan adanya ketidakseimbangan fisik dan psikis, yang mempengaruhi emosi, proses berpikir, dan kondisi seorang karyawan, dalam hal ini tekanan yang ada disebabkan oleh lingkungan pekerjaan di mana karyawan tersebut berkerja. Penelitian yang dilakukan
}

Yendrawati dan Mukti (2015), Ariyantini, Sujana, dan Darmawan (2014), Praditaningrum (2012), Margaret (2014), Rahmawati (2016), menunjukan adanya pengaruh negatif tekanan ketaatan terhadap audit judgment, dimana artinya semakin tinggi tingkat tekanan ketaatan yang diterima oleh seorang auditor maka audit judgment yang dihasilkan akan cenderung kurang tepat. Sementara itu penelitian yang dilakukan Agustini dan Merkusiwati (2016) dan Kusumawardhani (2015) menunjukan adanya pengaruh yang positif antara tekanan ketaatan terhadap audit judgment yang dilakukan oleh seorang auditor, yang artinya semakin tinggi tingkat tekanan ketaatan seorang auditor, maka judgment yang dihasilkan akan semakin baik pula.

Seorang auditor yang menerima tekanan baik dari atasan ataupun kliennya cenderung akan melakukan tindakan yang menyimpang serta menghasilkan judgment yang tidak baik dan tidak tepat, jika dibandingkan dengan auditor yang tidak menerima tekanan dari pihak manapun dan memegang teguh standar profesional yang telah ditetapkan, tentu auditor yang menjalankan tugasnya tanpa menerima tekanan dari pihak manapun akan menghasilkan suatu judgment yang jauh lebih baik dan lebih tepat. Berdasarkan uraian di atas dan hasil penelitian sebelumnya, maka dapat dirumuskan hipotesis sebagai berikut:

\section{H2: Tekanan Ketaatan Berpengaruh Terhadap Audit Judgment}

Kompleksitas tugas dapat diartikan sebagai tingkat kesulitan dan variasi pekerjaan terutama dalam bentuk tekanan terhadap mental dan psikis orang yang melakukan pekerjaan (Ruky, 2011). Penelitian yang dilakukan oleh Yendrawati dan Mukti (2015), Dewi (2016), Raiyani dan Suputra (2014), dan Surtikanti (2016) menyimpulkan kompleksitas tugas berpengaruh positif terhadap audit judgment, di mana semakin tinggi kompleksitas tugas yang dihadapi oleh seorang auditor maka judgment yang dihasilkan akan semakin baik. Sementara penelitian yang dilakukan oleh Ariyantini, Sujana, dan 
Darmawan (2014), Margaret (2014), Rahmawati (2016), dan Maengkom (2016), menunjukan pengaruh negatif kompleksitas tugas terhadap audit judgment, artinya semakin tinggi tingkat kompeksitas tugas yang dihadapi seorang auditor maka judgment yang dihasilkan akan cenderung kurang tepat.

Kompleksitas tugas yang tinggi akan mempengaruhi seorang auditor dalam menghasilkan suatu judgment, semakin kompleks tugas yang dihadapinya, maka judgment yang dihasilkan akan cenderung kurang baik dan kurang tepat, karena baik seorang auditor ataupun pekerja-pekerja profesi lain nya pasti akan kesulitan menghasilkan sesuatu yang baik dan maksimal ketika dihadapkan pada suatu tugas dengan tingkat kompleksitas yang tinggi. Berdasarkan uraian di atas dan hasil penelitian sebelumnya, maka dapat dirumuskan hipotesis sebagai berikut:

\section{H3: Kompeksitas Tugas Berpengaruh Terhadap Audit Judgment}

\section{METODOLOGI PENELITIAN Jenis Penelitian}

Penelitian ini dilakukan dengan menggunakan pendekatan kuantitatif, yaitu penelitian yang analisisnya lebih fokus pada data-data numerikal (angka) yang diolah dengan menggunakan metode statistika. Metode penelitian yang digunakan adalah metode survei, menurut Sugiyono (2013) metode survei digunakan untuk mendapatkan data dari tempat tertentu dengan cara peneliti melakukan pengumpulan data misalnya dengan membagikan kuesioner, test, dan wawancara terstruktur.

\section{Variabel Pengukuran Audit Judgment}

Audit judgment merupakan variabel dependen yang diukur dengan mengadopsi instrumen yang digunakan oleh Jamilah, dkk (2007), yang diukur dengan skala Likert lima point yaitu (1) sangat tidak mungkin; (2) tidak mungkin; (3) netral; (4) mungkin; dan (5) sangat mungkin.

\section{Locus of Control}

Locus of Control diukur dengan mengadopsi instrumen The Work Locus of Control Scale (WLCS) yang dikembangkan oleh Spector (1988) dan digunakan oleh Zoraifi (2005). Variabel ini diukur dengan menggunakan skala likert 5 (lima) poin yaitu (1) sangat tidak setuju; (2) tidak setuju; (3) netral; (4) setuju; dan (5) sangat setuju.

\section{Tekanan Ketaatan}

Tekanan ketaatan diukur dengan mengadopsi instrumen yang digunakan oleh Jamilah, dkk (2007) . Variabel ini diukur dengan skala Likert lima (lima) poin yaitu (1) sangat tidak setuju; (2) tidak setuju; (3) netral; (4) setuju; dan (5) sangat setuju.

\section{Kompleksitas Tugas}

Kompleksitas tugas diukur dengan mengadopsi instrumen yang digunakan oleh Jamilah, dkk (2007), yaitu diukur dengan skala Likert 5 (lima) poin yaitu (1) sangat salah; (2) salah; (3) netral; (4) benar; dan (5) sangat benar.

\section{Populasi dan Sampel}

Populasi penelitian ini adalah seluruh auditor yang bekerja pada Kantor Akuntan Publik yang terdaftar pada Directory Institut Akuntan Publik Indonesia (IAPI) untuk wilayah Tangerang per Oktober 2016. Teknik pengambilan sampel di dalam penelitian ini menggunakan teknik nonprobability sampling dengan tipe purposive sampling. Maka ditetapkan kriteria sampel pada penelitian ini adalah: (1) Auditor pada kantor akuntan publik yang bersedia menerima dan mengisi kuesioner; (2) Auditor yang bekerja pada Kantor Akuntan Publik di wilayah Tangerang; (3) Dengan tingkatan auditor junior, auditor senior, supervisor, dan manajer; dan (4) Telah berkerja sebagai auditor minimal 1 (satu) tahun. Penetapan kriteria-kriteria diatas supaya nantinya sampel yang didapat lebih representatif karena diasumsikan sampel tersebut dapat lebih memahami dan mengerti permasalahan yang sedang diteliti menyangkut locus of control, tekanan ketaatan, kompleksitas tugas, dan audit judgment. 


\section{Teknik Pengumpulan Data}

Jenis data yang digunakan dalam penelitian ini adalah data primer, yaitu data yang diperoleh melalui penyebaran angket (kuesioner). Kuesioner ini akan berisi butirbutir pertanyaan tentang variabel locus of control, tekanan ketaatan, kompleksitas tugas, dan audit judgment. Kategori kuesioner dalam penelitian ini adalah kuesioner tertutup, yaitu kuesioner yang telah menyediakan pilihan jawaban untuk dipilih oleh objek penelitian.

\section{Teknik Analisis Data}

Metode analisis data yang digunakan pada penelitian ini adalah analisis regresi linier berganda (Multiple Regression Analysis). Analisis ini dimaksudkan untuk mengungkapkan pengaruh antara beberapa variabel bebas dengan variabel terikat. Teknis analisis yang digunakan dalam penelitian ini meliputi statistik deskriptif, uji kualitas data, uji asumsi klasik, uji kelayakan model regresi, analisis regresi linier berganda dan uji hipotesis. Model regresi yang digunakan di dalam penelitian ini sebagai berikut:

$\mathrm{Y}=\mathrm{a}+\beta 2 X 2+\beta 2 X 2+\beta 3 X 3+\dot{\varepsilon}$

Keterangan:

$\mathrm{Y}=$ Audit Judgment

$\alpha=$ konstanta

$\mathrm{X} 1=$ Locus of Control

$\mathrm{X} 2=$ Tekanan Ketaatan

X3 = Kompleksitas Tugas

$\varepsilon=$ faktor penganggu atau error term

$\beta 1 \ldots \beta 3=$ koefisien regresi yang akan dihitung

\section{HASIL DAN PEMBAHASAN Hasil Penelitian}

Penelitian ini dilakukan pada Januari 2017 di Kantor Akuntan Publik wilayah Tangerang, terdapat 5 (lima) Kantor Akuntan Publik yang bersedia menerima kuesioner. Dari kelima Kantor Akuntan Publik telah tersebar kuesioner berjumlah 70 buah. Jumlah kuesioner yang dikembalikan berjumlah 55 dan dari jumlah itu, 52 buah telah memenuhi kriteria untuk dijadikan sampel sedangkan 3 lainnya tidak memenuhi kriteria sampel. Jumlah 52 responden ini telah memenuhi minimum sampel suatu penelitian yaitu minimal 30 serta telah memenuhi ketentuan 10x (kali) dari jumlah variabel yang digunakan yaitu $10 \times 4=40$, sehingga bisa digunakan sebagai sampel penelitian.

Berdasarkan uji statistik deskriptif didapatkan hasil yaitu audit judgment memiliki nilai mean sebesar 27,56 dengan nilai standar deviasi sebesar 5,23. Locus of control memiliki nilai mean sebesar 60,42 dengan nilai standar deviasi sebesar 5,56. Tekanan ketaatan memiliki nilai mean sebesar 33,11 dengan nilai standar deviasi sebesar 5,41. Dan kompleksitas tugas memiliki nilai mean sebesar 21,54 dengan nilai standar deviasi sebesar 3,73. Nilai mean yang lebih besar dari nilai standar deviasi mengindikasikan jika data yang digunakan di dalam penelitian baik dan normal.

Uji kualitas data terdiri dari uji reliabilitas dan uji validitas. Berdasarkan uji reliabilitas dapat disimpulkan jika semua instrumen penelitian yang digunakan reliable karena memiliki nilai cronbach's alpha $>70$, di mana audit judgment memiliki cronbach's alpha 0,780 ; locus of control 0,715 ; tekanan ketaatan 0,782; dan kompleksitas tugas 0,727. Berdasarkan uji validitas masing-masing item pertanyaan dari variabel audit judgment, locus of control, tekanan ketaatan dan kompleksitas tugas menunjukan nilai lebih besar dari $\mathrm{r}$ tabelnya yaitu sebesar 0,2787. Sehingga dapat disimpulkan jika seluruh item pertanyaan yang digunakan valid.

Uji asumsi klasik terdiri dari uji normalitas, uji mutikolonieritas, dan uji heteroskedastisitas. Uji normalitas didalam penelitian ini menggunakan uji Kolmogorov Smirnov, berdasarkan uji tersebut data penelitian ini berdistribusi normal karena nilai Asymp. Sig. (2-tailed) nya lebih besar dari 0,05, yaitu sebesar 0,175. Berdasarkan uji multikolonieritas menunjukan jika nilai tolerance untuk ketika variabel independen lebih besar dari 0,1 sedangkan nilai VIF nya kurang dari 10. Locus of control memiliki nilai tolerance 0,758 dengan nilai VIF 1,319; tekanan ketaatan memiliki nilai tolerance 0,699 dengan nilai VIF 1,431; dan kompleksitas tugas memiliki nilai tolerance 0,628 dengan nilai VIF 1,592 . Hal ini berarti variabel independen di dalam penelitian ini 
yaitu locus of control, tekanan ketaatan dan kompleksitas tugas tidak terjadi multikolonieritas. Uji heteroskedastisitas di dalam penelitian ini menggunakan uji Park. Nilai signifikasi yang dihasilkan oleh uji Park untuk ketiga variabel independen $>0,05$, dimana nilai signifikasi locus of control 0,205; tekanan ketaatan 0,491; dan kompeksitas tugas 0,194 . Hal ini berarti tidak terjadi heteroskedastisitas.

Uji kelayakan model regresi di dalam penelitian ini menggunakan uji $\mathrm{F}$, model regresi dikatakan layak jika nilai sig $<0,05$ dan $\mathrm{f}$ hitung $>\mathrm{f}$ tabel. Berdasarkan uji $\mathrm{F}$ yang dilakukan, model regresi yang digunakan di dalam penelitian ini layak dan dapat digunakan untuk memprediksi audit judgment karena nilai signya $<0,05$ yaitu $0,000<0,05$ dan nilai f hitung $>$ dari f tabelnya yaitu 24,707 >0,005.

Berdasarkan hasil uji koefisien korelasi didapati nilai sebesar 0,779 hal ini menunjukan bahwa audit judgment memiliki korelasi positif yang sangat kuat dengan locus of control, tekanan ketaatan dan kompleksitas tugas. Berdasarkan uji koefisien determinasi, dapat diketahui bahwa koefisien determinasi dalam penelitian ini adalah 0,582 atau $58,2 \%$. Hal ini berarti bahwa $58,2 \%$ dari audit judgment dapat dijelaskan oleh variabel locus of control, tekanan ketaatan dan kompleksitas tugas, sedangkan sisanya yaitu $41,8 \%$ dipengaruhi oleh faktor-faktor lain yang tidak dijelaskan dalam model.

Berdasarkan hasil uji regresi linier berganda, maka dapat diketahui bentuk persamaannya sebagai berikut:

$\mathrm{Y}=36,118+0,310 \mathrm{X} 1-0,431 \mathrm{X} 2-0,605 \mathrm{X} 3$

Sehingga berdasarkan persamaan di atas dapat dijelaskan pengaruh locus of control, tekanan ketaatan, dan kompleksitas tugas terhadap audit judgment adalah sebagai berikut:

1. Nilai konstanta sebesar 36,118 . Hal ini berarti apabila locus of control (X1), tekanan ketaatan (X2), dan kompleksitas tugas (X3) nilainya adalah nol maka nilai audit judgment sebesar 36,118.

2. Nilai koefisien locus of control sebagai variabel X1 sebesar 0,310 dan bertanda positif. Hal ini berarti apabila locus of control mengalami kenaikan 1\%, maka audit judgment (Y) akan naik sebesar 0,310 atau $31 \%$ dengan asumsi bahwa variabel independen yang lain dari model regresi adalah tetap.

3. Nilai koefisien tekanan ketaatan sebagai variabel X2 sebesar 0,431 dan bertanda negatif, hal ini menunjukan bahwa tekanan ketaatan mempunyai hubungan yang berlawanan arah dengan audit judgment. Hal ini berarti apabila tekanan ketaatan mengalami kenaikan 1\%, maka audit judgment (Y) akan turun sebesar 0,431 atau $43,1 \%$ dengan asumsi bahwa variabel independen yang lain dari model regresi adalah tetap.

4. Nilai koefisien kompleksitas tugas sebagai variabel X3 sebesar 0,605 dan bertanda negatif, hal ini menunjukan bahwa kompleksitas tugas mempunyai hubungan yang berlawanan arah dengan audit judgment. Hal ini berarti apabila kompleksitas tugas mengalami kenaikan $1 \%$, maka audit judgment (Y) akan turun sebesar 0,605 atau $60,5 \%$ dengan asumsi bahwa variabel independen yang lain dari model regresi adalah tetap.

Berdasarkan hasil uji hipotesis (uji $t$ ), diperoleh hasil sebagai berikut:

1. Nilai signifikan variabel locus of control sebesar $0,003<0,05 \quad$ dengan unstandardized coefficients (B) bernilai positif, ini artinya variabel locus of control berpengaruh signifikan dengan arah hubungan yang positif terhadap audit judgment. Sehingga dapat disimpulkan jika H1 diterima.

2. Nilai signifikan variabel tekanan ketaatan sebesar $0,000<0,05 \quad$ dengan unstandardized coefficients (B) bernilai negatif, ini artinya variabel tekanan ketaatan berpengaruh signifikan dengan arah hubungan yang negatif terhadap audit judgment. Sehingga dapat disimpulkan jika $\mathrm{H} 2$ diterima.

3. Nilai signifikan variabel kompleksitas tugas sebesar $0,000<0,05$ dengan unstandardized coefficients (B) bernilai negatif, ini artinya variabel kompleksitas tugas berpengaruh signifikan dengan arah hubungan yang negatif terhadap audit 
judgment. Sehingga dapat disimpulkan jika $\mathrm{H} 3$ diterima.

\section{Pembahasan \\ Pengaruh Locus of Control Terhadap Audit Judgment}

Hasil penelitian ini menunjukan bahwa locus of control berpengaruh signifikan positif terhadap audit judgment. Variabel locus of control mempunyai nilai signifikasi sebesar 0,003 . Berdasarkan hasil tersebut karena nilai signifikansinya lebih kecil dari nilai alpha yang ditentukan yaitu sebesar 0,05, maka dapat disimpulkan bahwa hipotesis pertama diterima. Hasil penelitian ini mendukung penelitian yang dilakukan oleh Retnowati (2009), Raiyani dan Suputra (2014), Mahaputra (2016), dan Dewi (2016) yang menyatakan bahwa locus of control berpengaruh signifikan positif terhadap audit judgment, ini artinya semakin tinggi tingkat locus of control yang dimiliki oleh seorang auditor maka audit judgment yang dihasilkannya akan semakin baik.

Hasil penelitian ini menandakan semakin baik cara pandang auditor terhadap suatu peristiwa maka akan semakin baik kinerjanya dalam menentukan suatu audit judgment. Auditor yang memiliki locus of control tinggi dapat mengatasi stres dan lingkungan kerja yang lebih baik. Auditor dengan locus of control yang tinggi akan membuat auditor tersebut lebih tepat dalam menentukan suatu judgment, karena dengan locus of control yang tinggi seorang auditor dapat menggolongkan dan menganalisa dari setiap faktor atau penyebab keberhasilan dan kegagalannya dalam melakukan proses audit dengan lebih tepat. Semakin tinggi tingkat locus of control yang dimiliki oleh seorang auditor, maka akan memotivasi auditor untuk meminimalisir faktor penyebab kegagalannya dan memaksimalkan faktor penyebab dari keberhasilannya.

\section{Pengaruh Tekanan Ketaatan Terhadap Audit Judgment}

Hasil penelitian ini menunjukan bahwa tekanan ketaatan berpengaruh signifikan negatif terhadap audit judgment. Variabel tekanan ketaatan mempunyai nilai signifikasi sebesar 0,000. Berdasarkan hasil tersebut karena nilai signifikasinya lebih kecil dari nilai alpha yang ditentukan yaitu sebesar 0,05 , maka dapat disimpulkan bahwa hipotesis kedua diterima. Hasil penelitian ini konsisten dengan penelitian yang dilakukan oleh Praditaningrum (2012), Ariyantini, dkk (2014), Margaret (2014),Yendrawati dan Mukti (2015), dan Rahmawati (2016) yang menyimpulkan bahwa tekanan ketaatan berpengaruh signifikan negatif terhadap audit judgment, hal ini menandakan semakin tinggi tekanan ketaatan yang diterima oleh seorang auditor maka audit judgment yang dihasilkan akan cenderung kurang tepat.

Perbedaan harapan antara entitas yang diperiksa dengan auditor merupakan hal yang menyebabkan tekanan ketaatan terjadi. Pada saat perbedaan harapan itu terjadi, maka entitas yang diperiksa akan berusaha untuk menekan auditor untuk menyamakan harapannya. Maka akan muncul suatu konflik antara auditor dengan entitas yang diperiksa. Pada saat konflik ini terjadi, muncullah tekanan dari atasan. Tekanan atasan ini berupa perintah untuk menyimpang dari standar yang telah ditentukan. Pada kondisi seperti ini akan muncul dilema etika pada auditor. Kondisi adanya perintah dari atasan dan tekanan dari entitas yang diaudit untuk berperilaku menyimpang dari standar profesional membuat auditor junior cenderung akan menaati perintah tersebut. Hal ini juga menunjukan bahwa auditor junior tidak memiliki keberanian untuk tidak menaati perintah atasan dan keinginan entitas yang diaudit untuk berpindah walaupun instruksi tersebut tidak tepat. Adanya sanksi terhadap perintah atasan jika tidak dijalankan, akan menyebabkan dilema etika mengarahkan auditor pada pengambilan keputusan yang salah yaitu menaati perintah atasan. Sanksi yang didapatkan apabila auditor tidak menaati perintah atasan berupa keterlambatan jenjang karier akibat pemberhentian penugasan di entitas tersebut. Sehingga tekanan ketaatan akan berdampak terhadap audit judgment yang dilakukan. 


\section{Pengaruh Kompleksitas Tugas Terhadap Audit Judgment}

Hasil penelitian ini menunjukan bahwa kompleksitas tugas berpengaruh signifikan negatif terhadap audit judgment. Variabel kompleksitas tugas mempunyai nilai signifikasi sebesar 0,000. Berdasarkan hasil tersebut karena tingkat signifikansinya lebih kecil dari nilai alpha yang ditentukan yaitu sebesar 0,05, maka dapat disimpulkan bahwa hipotesis ketiga diterima. Penelitian ini konsisten dengan penelitian yang dilakukan oleh Ariyantini, dkk (2014), Margaret (2014), Rahmawati (2016), dan Maengkom (2016) yang menyatakan bahwa kompleksitas tugas berpengaruh signifikan negatif terhadap audit judgment, ini artinya semakin kompleksnya tugas yang dihadapi seorang auditor maka audit judgment yang dihasilkan akan cenderung kurang tepat.

Tugas yang sulit, tidak terstruktur dan membingungkan merupakan maksud dari kompleksitas tugas. Kompleksitas tugas terdiri dari dua komponen yaitu kesulitan tugas dan struktur tugas. Tugas yang sulit membutuhkan lebih banyak kemampuan individu untuk menyelesaikannya. Jika kesulitan tugas lebih besar daripada kemampuan individu, maka memicu adanya kekhawatiran akan terjadi kegagalan di dalam penyelesaian tugas, maka akan berakibat pada menurunnya motivasi dan usaha untuk menyelesaikan tugas sehingga kinerjanya menurun. Penurunan kinerja ini juga akan berdampak pada kualitas audit judgment yang dihasilkan. Hal ini mengindikasikan semakin kompleks tugas yang dihadapi seorang auditor, maka auditor menjadi tidak mampu mengintegrasikan informasi menjadi suatu judgment yang baik. Sehingga semakin tinggi kompleksitas tugas maka audit judgment yang dihasilkan akan cenderung kurang tepat.

\section{SIMPULAN}

\section{Kesimpulan}

Berdasarkan analisis dan pembahasan tentang pengaruh locus of control, tekanan ketaatan, dan kompleksitas tugas terhadap audit judgment, maka dapat ditarik kesimpulan sebagai berikut:
1. Locus of control berpengaruh signifikan positif terhadap audit judgment. Sejalan dengan hasil penelitian yang dilakukan oleh Retnowati (2009) Raiyani dan Suputra (2014), Mahaputra (2016), dan Dewi (2016).

2. Tekanan ketaatan berpengaruh signifikan negatif terhadap audit judgment. Sejalan dengan penelitian yang dilakukan oleh Praditaningrum (2012), Ariyantini, dkk (2014), Margaret (2014) Yendrawati dan Mukti (2015), dan Rahmawati (2016).

3. Kompleksitas tugas berpengaruh signifikan negatif terhadap audit judgment. Sejalan dengan penelitian yang dilakukan oleh Ariyantini, dkk (2014), Margaret (2014), Rahmawati (2016) dan Maengkom (2016).

\section{Keterbatasan Penelitian}

Peneliti mengakui bahwa dalam penelitian ini terdapat banyak keterbatasan yang memungkinkan dapat memberikan gangguan pada hasil penelitian. Keterbatasanketerbatasannya sebagai berikut:

1. Penelitian ini menggunakan jumlah responden yang sangat terbatas. Terbatasnya jumlah responden yang diperoleh tentu mengurangi derajat keterwakilan bagi auditor yang lain yang tidak menjadi responden.

2. Penyebaran kuesioner dalam penelitian ini tidak dapat dilakukan secara maksimal karena berbagai halangan, seperti kesibukan auditor hingga penolakan dari Kantor Akuntan Publik.

3. Penelitian ini menggunakan metode survei melalui kuesioner, peneliti tidak melakukan wawancara atau terlibat langsung dalam aktivitas di Kantor Akuntan Publik, sehingga data yang diperoleh hanya berdasarkan pada data yang dikumpulkan melalui instrumen secara tertulis, alhasil jawaban kuesioner rentan diisi dengan tidak serius atau asalasalan.

\section{Saran}

Berdasarkan hasil dari penelitian yang dilakukan dan keterbatasan dari penelitian ini, 
maka dapat diberikan saran-saran sebagai berikut:

1. Penelitian selanjutnya diharapkan dapat memperluas lingkup wilayah, tidak hanya Kantor Akuntan Publik di wilayah Tangerang tetapi juga menggunakan Kantor Akuntan Publik yang berada di luar wilayah Tangerang, sehingga dapat menghasilkan penelitian yang lebih baik serta jumlah sampel yang lebih banyak.

2. Penelitian selanjutnya diharapkan dapat meyakinkan pimpinan Kantor Akuntan Publik untuk dapat bekerja sama agar kemungkinan penolakan dapat diminimalisir, sehingga penelitian yang dilakukan nantinya akan lebih baik.

3. Penelitian selanjutnya sebaiknya mengunakan instrumen selain kuesioner, agar data yang diperoleh lebih bisa menggambarkan objek penelitian secara keseluruhan.

4. Penelitian selanjutnya diharapkan mampu mengembangkan dengan menambah variabel lain selain variabel independen yang telah digunakan pada penelitian ini, seperti tekanan anggaran waktu, kompetensi, skeptisme profesional, self esteem, self efficacy, framing, dan keahlian audit.

\section{DAFTAR PUSTAKA}

Agustini, Ni Ketut Riski dan Ni Ketut Lely Aryani Merkusiwati. 2016. Pengaruh Tekanan Ketaatan, Senioritas Auditor, dan Tekanan Anggaran Waktu Terhadap Audit Judgment. E-Jurnal Akuntansi Universitas Udayana. Vol.15:1, hal 433462.

Ariyantini, Evi, Edy Sujana dan Ari Surya Darmawan. 2014. Pengaruh Pengalaman Auditor, Tekanan Ketaatandan Kompleksitas Tugas Terhadap Audit Judgment.e-Journal S1 Ak Universitas Pendidikan Ganesha. Jurnal Akuntansi Program S1 (Volume 2 No.1 Tahun 2014)

Bachtiar, Emil. 2012. Kasus - Kasus Etika Bisnis dan Profesi. Jakarta: Salemba Empat.
Dewi, Ricca Rosalina. 2016. Pengaruh Locus of Control, Kompleksitas Tugas, Self Efficacy dan Persepsi Etis Terhadap Audit Judgment (Studi pada KAP di Kota Surakarta dan Semarang). Skripsi. Fakultas Ekonomi dan Binsnis Universitas Muhammadiyah Surakarta Engko, Cecilia., dan Gudono. 2007. Pengaruh Kompleksitas Tugas dan Locus of Control Terhadap Hubungan Antara Gaya Kepemimpinan dan Kepuasan Kerja Auditor. JAAI. Volume 11, No2: Desember. Hal 105-124.

Hogarth. R.M., dan H.J. Einhorn. 1992. Order Effects in Belief Updating: The Belief Adjustment Mode., Cognitive Psychology 24:1-55.

Jamilah, dkk. 2007. Pengaruh Gender, Tekanan Ketaatan, dan Kompleksitas Tugas Terhadap Audit Judgment. Proceeding SNA $X$ Universitas Hasanudin Makasar. AUEP-06.

Kahneman, et al. 2011. On ThePsychology of Prediction. United State : Penguin Books Ltd

Kreitner, Robert dan Angelo Kinicki, 2005. Perilaku Organisasi. Salemba Empat. Mc Graw Hill Education. Jakarta.

Kusumawardhani, Angga. 2015. Pengaruh Framing dan Tekanan Ketaatan Terhadap Persepsi Tentang Audit Judgment (Studi Kasus pada Mahasiswa Akuntansi S1 FE UNY angkatan 2012). Skripsi. Fakultas Ekonomi Universitas Negeri Yogyakarta.

Maengkom, Michael Chornelis. 20016. Pengaruh keahlian Audit, Kompleksitas Tugas, dan Locus of Control Eksternal Terhadap Audit Judgment (Studi Kasus pada Auditor BPK RI Perwakilan Prov. Sulawesi Selatan). Skripsi. Fakultas Ekonomi dan Bisnis Universitas Hasanuddin Makasar

Mahaputra, I Nyoman Kusuma Adnyana. 2016. Pengaruh Locus Of Control, Self Esteem, Self Efficacy Dan Tingkat Pendidikan Terhadap Kinerja Auditor Dalam Pembuatan Audit Judgment Pada Kantor Akuntan Publik Di Bali. Teks Seminar Nasional, Unmas Denpasar. 
Margaret, Agnes Novriana. 2014. Analisis Faktor- Faktor Yang Mempengaruhi Audit Judgment Pada Auditor BPK RI. Skripsi tidak diterbitkan. Semarang. Fakultas Ekonomika dan Bisnis Universitas Diponegoro.

Mayangsari, Sekar dan Puspa Wandanarum. 2013. Auditing Pendekatan Sektor Publik dan Privat. Jakarta: Media Bangsa.

McGregor, D. 1960. The Human Side of Enterprise. New York.

Nadhiroh, Siti Asih. 2010. PengaruhKompleksitas Tugas, Orientasi tujian, dan Self- Efficacy Terhadap Kinerja Auditor dalam PembuatanAudit Judgment (Studi Pada Kantor Akuntan Publik di Semarang). Skripsi tidak diterbitkan. Semarang: Universitas Diponogoro.

Praditaningrum, Anugrah Suci. 2012. Analisis Faktor-Faktor Yang Berpengaruh Terhadap Audit Judgment (Studi Pada BPK RI Perwakilan Provinsi Jawa Tengah). Skripsi tidak diterbitkan. Semarang. Fakultas Ekonomika dan Bisnis Universitas Diponegoro.

Rahmawati, Novita. 2016. Analisis Faktor Faktor yang mempengaruhi Auditor dalam Melakukan Audit Judgment (Studi Empiris pada KAP di Jawa Tengah dan DIY). Skripsi. Fakultas Ekonomi dan Bisnis Universitas Muhammadiyah Surakarta.

Raiyani, N.L. Kadek Puput \& Suputra, I. D. G. Dharma. 2014. Pengaruh Kompetensi, Kompleksitas Tugas, Dan Locus Of Control Terhadap Audit Judgment. EJurnal Akuntansi Universitas Udayana 6.3 (2014):429-438.

Restuningdiah, Nurika dan Nur Indriantoro. 2000. "Pengaruh Partisipasi Terhadap Kepuasan Pemakai Dalam Pengembangan Sistem Informasi dengan Kompleksitas Tugas, Kompleksitas Sistem, dan Pengaruh Pemakai Sebagai Moderating Variable". Jurnal Riset Akuntansi Indonesia, Vol. 3, No. 2, hal 119-133.
Retnowati, Reny. 2009. Pengaruh keahlian Audit, Kompleksitas Tugas, dan Locus of Control Terhadap Audit Judgment. Skripsi. Fakultas Ekonomi dan Ilmu Sosial Universitas UIN Syarif Hidayatullah.

Robbbins dan Judge. 2007. Perilaku Organisasi, Jakarta : Salemba Empat

Robbins, S.T. 2003. Perilaku Organisasi. Terjemahan Ahmad Fausi, 2006. Klaten: Indeks.

Ruky, Achmad S. 2011. Manajemen Penggajian dan Pengupahan untuk Karyawan Perusahaan. Jakarta : Gramedia Pustaka Utama.

Sugiyono, 2013. Metode Penelitian Kuantitatif, Kualitatif, dan $R \& D$. Bandung: Alfabeta.

Surtikanti. 2016. Pengaruh Kompleksitas Tugas dan Skeptisme Profesional Terhadap Audit Judgment (Studi Kasus pada KAP di Kota Bandung yang terdaftar di BPK RI). Jurnal: Universitas Komputer Indonesia.

Yendrawati, Reni dan Dheane Kurnia Mukti. 2015. Pengaruh Gender, Pengalaman Auditor, Kompleksitas Tugas, Tekanan Ketaatan, Kemampuan Kerja, dan Pengetahuan Auditor Terhadap Audit Judgment. Jurnal Inovasi dan Kewirausahaan. Vol.4:1, hal 1-8.

Yustrianthe, Rahmawati Hanny. 2012. Beberapa Faktor yang Mempengaruhi Audit Judgment Auditor Pemerintah. Jurnal Dinamika Akuntansi, Vol. 4, No. 2.

Zoraifi, Renata. 2005.Pengaruh Locus of Control, Tingkat Pendidikan, Pengalaman Kerja, dan Pertimbangan Etis Terhadap Perilaku Auditor Dalam Situasi Konflik Audit. Jurnal Akuntansi dan Bisnis, Vol 5, No.1. Surakarta: Jurusan Akuntansi FE Universitas Sebelas Maret. Februari. 12-26.

Zulaikha. 2006. Pengaruh Interaksi Gender, Kompleksitas Tugas dan Pengalaman Auditor terhadap Audit Judgment. SNA $I X$, Padang, Agustus.

Http://www. iapi.or.id/kap diakses tanggal 26 Oktober 2016. 